\title{
ANALISA DAN IMPLEMENTASI E-COMMERCE PADA BBDC SCREEN PRINTING DENGAN PENDEKATAN BUSINESS MODEL CANVAS DAN CONTENT MANAGEMENT SYSTEM
}

\author{
Andi Surya Syach Alam Mannaungi ${ }^{1)}$, Agus Umar Hamdani ${ }^{2)}$ \\ ${ }^{1}$ Sistem Informasi, Fakultas Teknologi Informasi, Universitas Budi Luhur \\ ${ }^{1,2} \mathrm{Jl}$. Raya Ciledug, Petukangan Utara, Kebayoran Lama, Jakarta Selatan 12260 \\ E-mail : and.suryasyach@gmail.com ${ }^{1)}$, agus.umarhamdani@budiluhur.ac.id ${ }^{2)}$
}

\begin{abstract}
Abstrak
Perkembangan bisnis fashion yang terjadi saat ini membuat banyak masyarakat yang menginginkan kaos-kaos atau jaket yang mempunyai harga murah dengan kualitas yang bagus. Hal tersebut memicu banyak perkembangan toko-toko atau jasa sablon baju seperti toko BBDC Screen Printing. Selain berfokus pada penjualan jasa sablon baju, toko tersebut juga menyediakan kaos, jaket dan juga totebag. Beberapa permasalahan yang terjadi di Toko BBDC Screen Printing antara lain masih menggunakan toko fisik sebagai tempat promosi yang mengakibatkan ruang promosi menjadi yang sangat terbatas, letak toko yang kurang strategis menyebabkan banyak pelanggan yang kesulitan mendatangi toko, kesulitan untuk mengetahui informasi pendapatan berkala dan pengolahan transaksi masih dilakukan dengan cara tertulis dan pembukuan biasa. Untuk mengatasi masalah tersebut, maka peneliti memberikan solusi dengan pembuatan sistem ecommerce menggunakan content management system dengan tool berupa wordpress. Peneliti menggunakan metode Business Model Canvas untuk menganalisis model proses bisnis perusahaan, analisis dan desain sistem e-eommerce menggunakan pendekatan Object-Oriented Analysis and Design. Implementasi sistem E-Commerce menggunakan Content Management System. Dengan implemetasi prototype e-commerce ini,peneliti berharap ada peningkatan penjualan, ruang promosi yang luas, dan mampu mengatasi permasalahan yang terjadi pada toko BBDC Screen Printing.
\end{abstract}

Kata kunci: e-commerce, kaos, jaket, totebag,, content management system

\section{PENDAHULUAN}

Dengan perkembangan bisnis fashion yang ditandai dengan maraknya pertumbuhan factory outlet maupun usaha distro di jaman sekarang, menjadi pemicu meningatnya permitaan jasa sablon dikalangan masyarakat. Gaya fashion yang bervariatif menjadi kebutuhan tersediri bagi masyarakat. Dengan kemajuan ilmu teknologi yang sangat cepat di era saat ini, seiring dengan kebutuhan manusia yang juga terus bertambah. Sistem informasi dapat didefisinikan sebagai "suatu sistem didalam suatu organisasi yang mempertemukan kebutuhan pengolahan transaksi harian yang mendukung fungsi operasi organisasi yang bersifat manajerial dengan kegiatan strategi dari suatu organisasi untuk dapat menyediakan laporan-laporan yang diperlukan oleh pihak luar tertentu [1]. Salah satu teknologi sistem informasi yang berkembang pesat saat adalah teknologi $E$ Commerce. E-Commerce (Electronic Commerce) atau bisa disebut dengan perdagangan elektronik, salah satu aktifitas penjualan, pemasaran dan jasa melalui internet dan jaringan komputer yang sekarang biasa disebut belanja online. "Penjualan adalah bagian dari promosi dan promosi adalah salah satu keseluruhan sistem pemasaran" [2]. BBDC Screen Printing merupakan salah satu usaha yang bergerak dalam bidang sablon. "Sablon manual atau Screen Printing adalah teknik mencetak dalam berbagai media seperti kaos, kaos, plastik, kertas, kaca, kayu dan sebagainya dengan menggunakan alat bantu berupa screen sablon (atau sering juga disebut film sablon)”. Solusi yang diajukan untuk mengatasi masalah BBDC Screen Printing dalam pengolahan data dan untuk mengembangkan bisnis penjualannya yaitu e-commerce. Keuntungan yang diperoleh dengan menggunakan transaksi melalui $e$ commerce adalah untuk meningkatkan pendapatan dengan menggunakan penjualan online yang biayanya lebih murah dan juga sekaligus biaya-biaya operasional seperti kertas, pencetakan katalog dan sebagainya. Dalam penelitian ini, penulis menggunakan salah satu Content Management System yang paling banyak digunakan yaitu Wordpress. Beberapa studi literatur yang menjadi rujukan bagi penulis, antara lain : rujukan pertama yang berjudul "Sistem Penjualan Berbasis Web (ECommerce) Pada Tata Distro Kabupaten Pacitan” yang membahas aplikasi untuk memudahkan pengelolaan, penjualan produk dan promosi produk, serta memudahkan pembeli dalam melakukan transaksi [3], rujukan kedua berjudul "Sistem Informasi Penjualan Kaos Berbasis Web Pada Distro Sickness Berbasis E-commerce" yang membahas 
pembuatan website untuk penjualan E-Commerce dengan penyediaan informasi-informasi yang up to date mengenai produk-produk Distro Sickness [4], rujukan ketiga berjudul "Sistem Penjualan Berbasis E-Commerce Menggunakan Metode Objek Oriented pada Distro Dlapak Street Wear” yang membahas pembuatan aplikasi E-Commerce dengan tujuan untuk perluasan cakupan promosi, membantu pelanggan dari luar kota dan memaksimalkan pemasaran produk [5] dan rujukan terakhir berjudul "Model E-Commerce dengan metode Web Engineering Method untuk menunjang pemasaran produk pada XYZ Pet Shop" yang membahas pembuatan aplikasi E-Commerce untuk memasarkan produk makanan dan aksesoris hewan ternak [6].

\section{METODE PENELITIAN}

Tahapan penelitian yang peneliti lakukan dapat dilihat pada gambar 1 berikut ini :

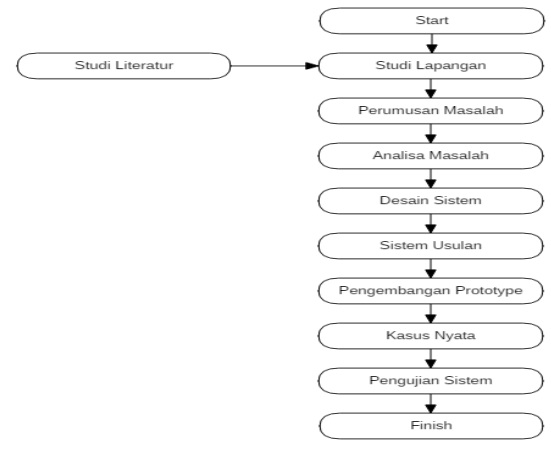

Gambar 1. Tahapan Penelitian

Berikut ini adalah penjelasan mengenai tahapan penelitian diatas :

a. Studi Lapangan

Dalam metode ini dilakukan dengan cara penulis datang langsung untuk melakukan observasi atau pengamatan dan wawancara dalam proses memperoleh keterangan atau data dengan cara terjun langsung ke lapangan.

b. Studi Literatur

Pada tahap ini dilakukan studi pustaka untuk memperoleh informasi berupa teori-teori yang mendukung permasalahan yang berkaitan dengan pengembangan strategi bisnis dengan metode BMC (Business Model Canvas) pada BBDC Screen Printing. Hal ini dapat diperoleh dari literaturliteratur atau jurnal yang membahas tentang metode tersebut. Pemilihan studi literatur sebaiknya pustaka terbaru dan relevan sehingga dapat menunjang peneliti dalam melakukan penelitian dan mencapai tujuan yang akan dicapai dalam sebuah penelitian.

c. Perumusan Masalah
Penelitian ini tentang BBDC Screen Printing yang membutuhkan sebuah platform e-commerce berbasis website yang dapat merincikan produk dengan baik, mencatat data pemesanan dengan baik, dan melakukan rekapitulasi transaksi agar menjadi laporan yang tepat. BBDC Screen Printing juga membutuhkan sebuah platform e-commerce berbasis website agar mudah diakses melalui komputer kapan saja dan dimana saja.

d. Analisa Sistem

Pada tahapan ini akan dilakukan analisis terhadap kebutuhan-kebutuhan sistem dan perangkat keras terhadap sebuah pembentukan website $e$ commerce. Sistem yang dianalisis adalah sistem yang berisi informasi tentang segala sesuatu yang berkaitan dengan pembuatan website e-commerce, dan berkaitan dengan perumusan masalah yang telah dianalisa pada BBDC Screen Printing.

\section{e. Desain Sistem}

Pada tahapan ini berisi tentang desain dari sistem yang akan berjalan pada website e-commerce BBDC Screen Printing, dan melakukan perancagan sistem yang berkaitan dengan permasalahan yang ada dengan menggunakan perangkat pemodelan sistem. Pada tahapan ini juga bersisi tentang pembuatan pemodelan sistem yang akan berjalan seperti Activity diagram, use case diagaram, basis data, rancangan layar, Sistem Sequence diagram, Class diagram, dan BMC (Business Model Canvas).

f. Sistem Usulan

Tahapan ini adalaha tahapan yang berisi dari hasil-hasil pemodelan sistem yang telah dilakukan pada tahapan sebelumnya, yaitu pada tahapan desain sistem. Dan pada tahapan ini juga berfungsi sebagai sistem usulan yang nantinya akan berjalan pada website e-commerce BBDC Screen Printing sebagai solusi dalam penyelesaian masalah yang ada.

\section{g. Pengembangan Prototype}

Didalam tahapan Development berisi bagian tentang pengembangan Prototype yang dimana pada bagian ini dilakukannya pengembangan terhadap sistem yang akan berjalan. Pada bagian ini juga akan dilakukannnya pembuatan aplikasi yang sesuai berdasarkan sistem yang telah dianalisapada tahapan sebelumnya.

h. Kasus Nyata

Pada bagian sebagai dasar dari uji kelayakan dari pembuatan website e-commerce untuk BBDC Screen Printing, apakah website e-commerce yang telah dibuat dan dapat menyelesaikan kasus atau masalah yang ada pada BBDC Screen Printing saat website e-commerce ini nantinya sudah berjalan dna digunakan.

\section{i. Pengujian Sistem}

Pada bagian ini website e-commerce yang telah dibuat akan dipresentasikan kepada pengguna untuk 
kelayakan dari website e-commerce yang telah dibuat, dan sebagai evaluasi terhadap website $e$ commerce yang telah dibuat yang nantinya akan dikembangkan kembali pada saat mendatang. Dari pengujian yang telah dilakukan maka menghasilkan sistem valid atau sistem yang sudah sesuai dengan kebutuhan dari pihak BBDC Screen Printing maupun pihak pengembangnya,

\section{HASIL DAN PEMBAHASAN}

\subsection{Analisis Business Model Canvas}

Berikut ini adalah BMC (Business Model Canvas) pada BBDC Screen Printing yang dapat dilihat pada gambar 2 berikut ini :

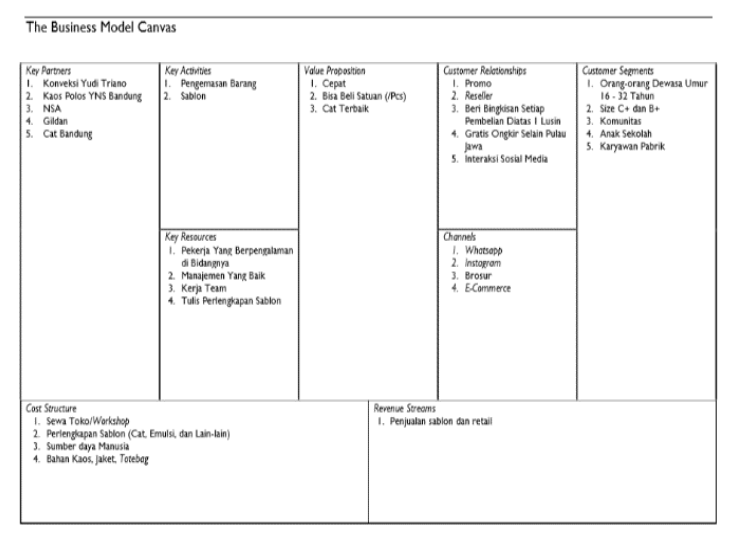

Gambar 2. Business Model Canvas dari toko BBDC Screen Printing

Uraian gambar BMC (Business Screen Printing) diuraikan sebagai berikut :

a. Customer Segments

Sasaran yang dituju untuk dijadikan sasaran pelanggan toko BBDC Screen Printing adalah orang-orang dewasa umur berusia dari 16 - 32 tahun. Selain itu sasaran Distro BBDC Screen Printing juga anak sekolah, Komunitas, dan pekerja pabrik selain itu menyediakan size $\mathrm{B}+$ dan $\mathrm{C}+$ untuk pelanggan yang memiliki badan besar.

b. Value Propositions

Kelebihan yang diberikan BBDC Screen Printing seperti mulai dari produk yang berkualitas dengan cat terbaik, menggunakan alat sablon yang berkualitas, bisa beli satuan (/pcs)dan desain produk yang tidak pasaran karna desain dapat disesuaikan.

c. Channels

Untuk pemasaran BBDC Screen Printing adalah Instagram dan Brosur sebagai media pemasaran digital yang utama. WhatsApp digunakan sebagai media komunikasi antara BBDC Screen Printing dengan pelanggan,

d. Customer Relationship

Mempertahankan pelanggan agar tetap memilih produk BBDC Screen Printing dengan cara memberikan informasi promo - promo yang sedang berlangsung memberikan promo gratis ongkos kirim kepada pelanggan yang disekitaran wilayah Jabodetabek.

e. Revenue Streams

BBDC Screen Printing produk utama yang dijual adalah sablon, baju dewasa, baju anak, jaket, dan totebag yang menjadi sumber pendapatan.

\section{f. Key Activities}

kegiatan dalam menjalankan bisnis BBDC Screen Printing adalah sablon kaos, sablon jaket, sablon totebag, custom model, pengemasan barang, dan promo menggunakan media sosial.

g. Key Resource

BBDC Screen Printing membutuhkan berbagai sumber daya agar bisnisnya dapat berjalan. Mulai dari bahan untuk membuat produk seperti sablon, baju dewasa, baju anak, jaket, totebag, karyawan toko dan pekerja sablon.

h. Key Parterns

Agar bisnis dapat berjalan dengan baik BBDC Screen Printing melakukan kerja sama dengan beberapa pihak yang terdiri dari konfeksi yudi triono, kaos polos YNS Bandung, NSA, Gildan, Cat sablon Bandung.

i. Cost Structure

Pembiayaan BBDC Screen Printing yaitu biaya pembelian bahan polos seperti baju, jaket, totebag, perlengkapan sablon, membayar gaji karyawan, dan biaya sewa toko.

\subsection{Activity Diagram Proses Pemesanan Produk}

Untuk melakukan pemesanan melalui website pelanggan harus mengakses website BBDC Screen Printing terlebih dahulu untuk dapat memilih produk yang akan dipesan dan mengklik produk yang diminati. Setelah itu, Sistem website akan mengarahkan pelanggan ke halaman pilih jenis produk untuk menampilkan jenis produk yang diminati. Kemudian, pelanggan memilih jenis sablon, ukuran, warna dan memasukkan jumlah yang akan dipesan. Setelah itu, pelanggan mengklik tombol add to cart. Lalu, muncul sidebar cart panel (keranjang belanja) yang sudah berisi produk yang sudah dipesan dari sistem website. Pelanggan dapat menambah produk lain dengan memilih kembali produk yang akan dipesan. Sesudah itu, pelanggan dapat mengklik tombol checkout. Kemudian, sistem website memproses pesanan tersebut. Jika pelanggan belum terdaftar di website BBDC Screen Printing maka pelanggan tidak bisa melanjutkan konfirmasi pesanan. Jika sudah melakukan login atau register maka pelanggan dapat melanjutkan proses konfirmasi pesanan berikutnya. Sesudah mendaftar akun di website BBDC Screen Printing pelanggan dapat melanjutkan proses konfirmasi pesanan dan akan diarahkan ke halaman checkout. Pelanggan 
dapat melihat detil pesanan dan upload gambar sablon serta melihat jumlah yang harus dibayar maka harus memasukan mengisi form detail tagihan terlebih dahulu seperti nama lengkap, telepon, email, alamat, provinsi, kota, kode pos (opsional), catatan (opsional). Setelah itu, Sistem website menampilkan pilihan jenis layanan jasa pengiriman. Saat ini pelanggan hanya dapat memilih kurir melalui JNE (Jalur Nugrah Eka kurir) sesudah memilih jenis layanan jasa pengiriman kemudian, sistem website akan menampilkan total pembayaran dan pelanggan dapat mengklik tombol buat pesanan. Lalu pelanggan diarahkan ke halaman yang menampilkan pesanan berhasil dibuat dan informasi mengenai detil pesanan serta akun bank BBDC Screen Printing untuk pelanggan dapat melakukan pembayaran. proses pemesanan barang dan proses Checkout dapat dilihat pada gambar 3 dan gambar 4 berikut ini :

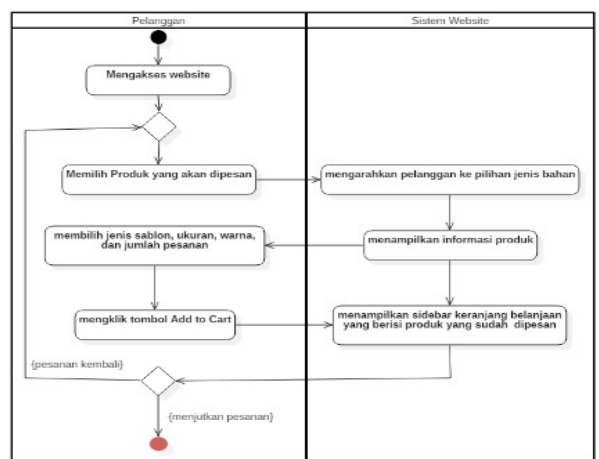

Gambar 3. Merupakan gambar Activity Diagram Proses Pemesanan Produk

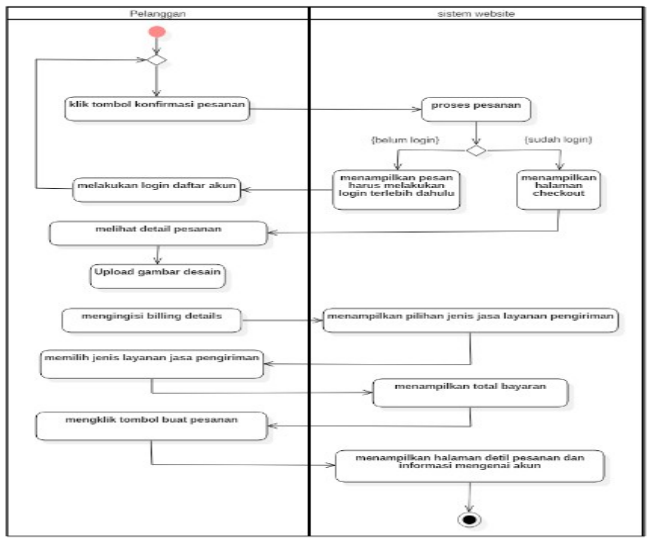

Gambar 4. Activity Diagram Proses Checkout

\subsection{Use Case Diagram}

Use case diagram ini digambarkan berdasarkan proses bisnis usulan yang diimplemantasikan pada e-commerce penjualan barang pada BBDC Screen Printing : a. Use Case Diagram Master

Berikut ini adalah model fungsional sistem pada use case diagram master yang dapat dilihat pada gambar 5 berikut ini :

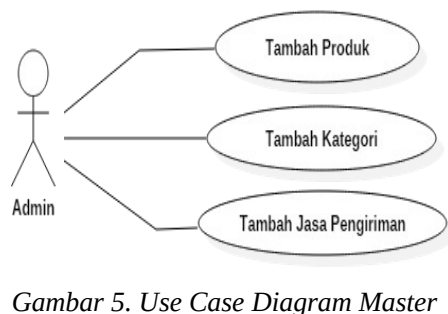

b. Use Case Diagram Transaksi

Berikut ini adalah model fungsional sistem pada use case diagram transaksi yang dapat dilihat pada gambar 6 berikut ini :
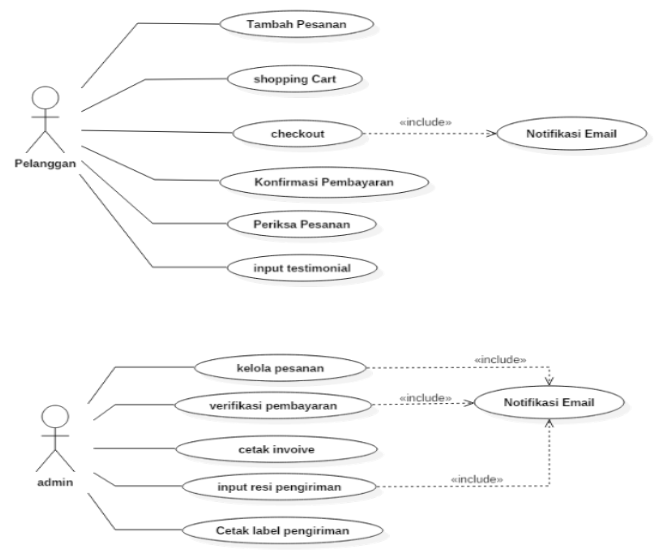

Gambar 6. Use Case Diagram Transaksi

c. Use Case Diagram Laporan

Berikut ini adalah model fungsional sistem pada use case diagram laporan yang dapat dilihat pada gambar 8 berikut ini :

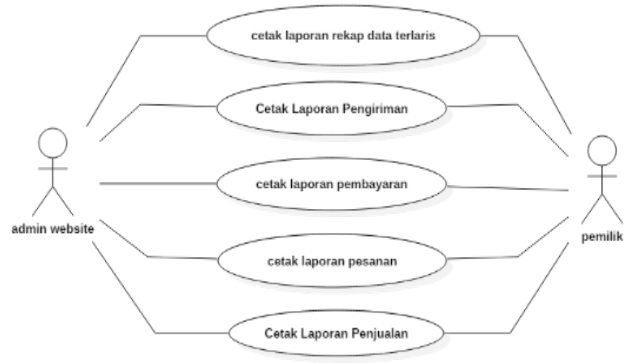

Gambar 7. Use Case Diagram Laporan

\subsection{Class Diagram}

Class Diagram yang digunakan pada sistem website e-commerce pada BBDC Screen Printing dapat dilihat pada gambar 8 berikut ini : 


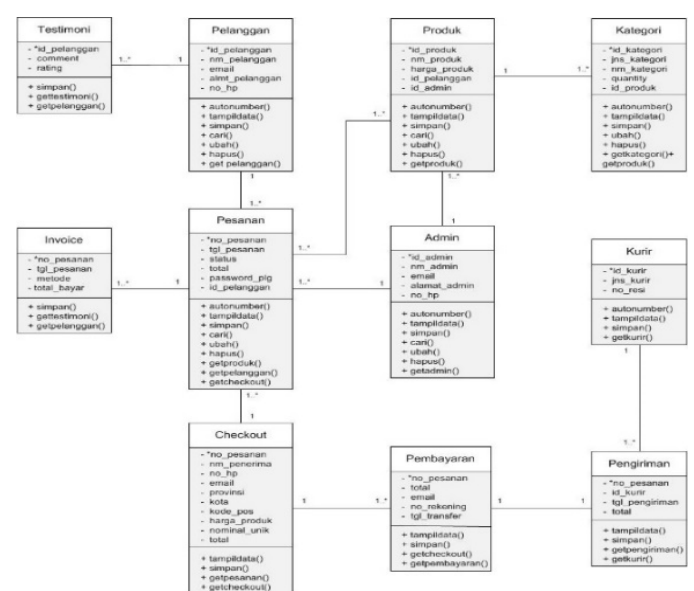

Gambar 8. Class Diagram

\subsection{Struktur Tampilan Menu}

Berikut ini dijelaskan mengenai struktur tampilan pada website E-Commerce Penjualan Barang pada BBDC Screen Printing :

a. Front-end

Struktur menu yang hanya bisa dilihat oleh pelanggan dapat dilihat pada gambar 9 berikut ini :

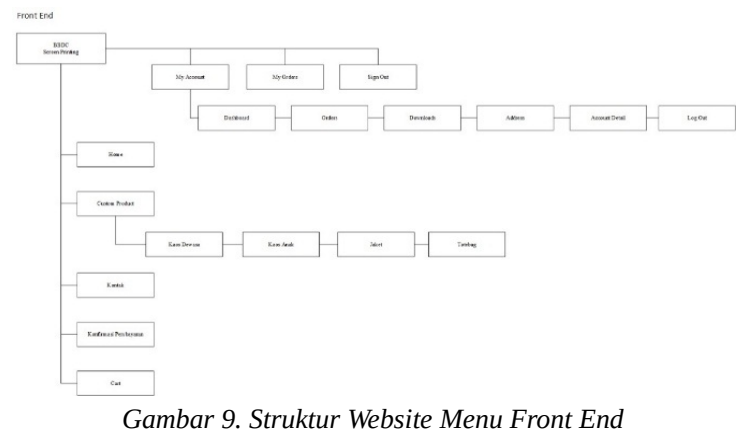

b. Back-end

Struktur menu-yang peruntukkan bagi staf admin dalam pengolahan website dapat dilihat pada gambar 10 berikut ini :

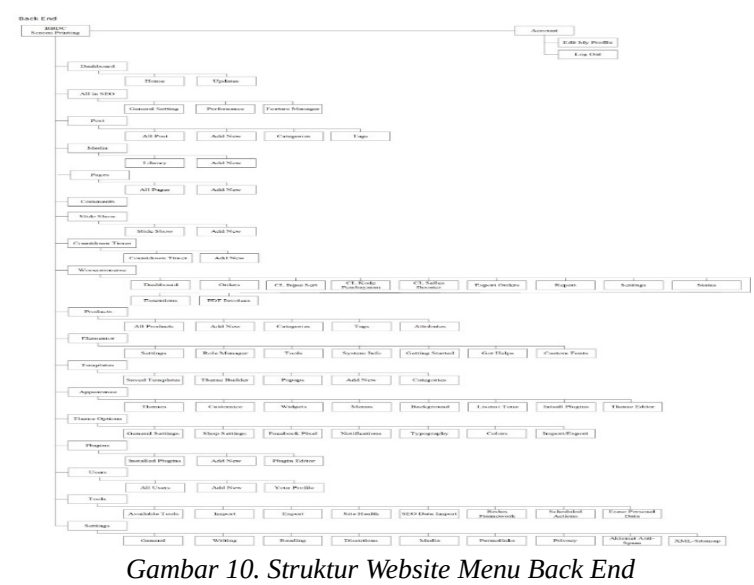

\subsection{Rancangan Layar}

Adapun beberapa rancangan layar yang penulis buat dibawah ini:

a. Rancangan layar checkout

Pada rancangan layar ini pelanggan memasukkan data beserta alamat pengiriman barang, pengecekkan harga total barang pesanan, memasukkan desain sablon, dan memilih jasa pengiriman yang digunakan dapat dilihat pada gambar 11 berikut ini :

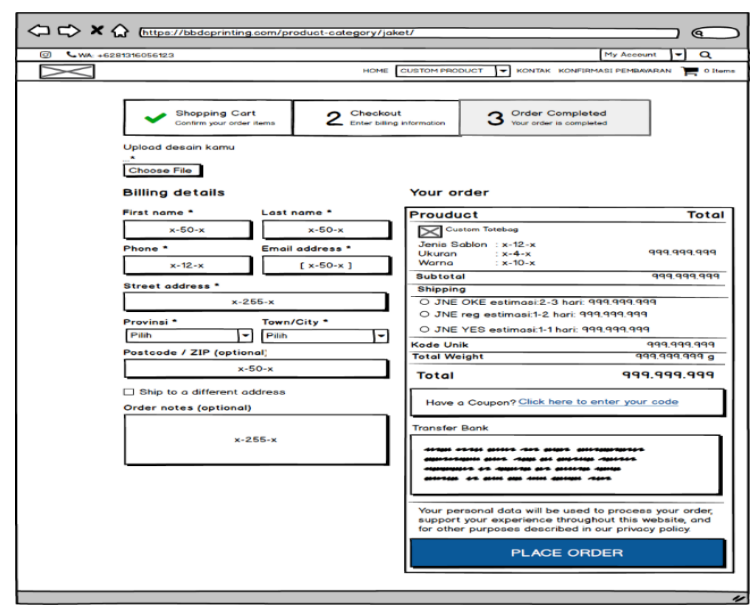

Gambar 11. Rancangan layar Checkout

b. Rancangan Layar Kelola Pesanan

Rancangan layar untuk mengelola setiap pesanan yang masuk maupun yang keluar dapat dilihat pada gambar 12 berikut ini : 


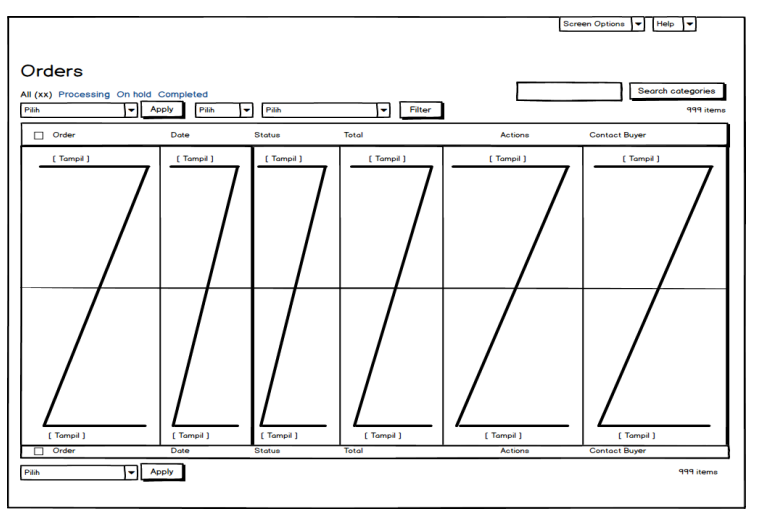

Gambar 12. Rancangan Layar Kelola Pesanan

\subsection{System sequence Diagram}

Adapun beberapa system sequence diagram yang digambarkan menggunakan microsoft visio:

a. System sequence diagram checkout

System sequence diagram untuk aktivitas checkout dapat dilihat pada gambar 13 berikut ini :

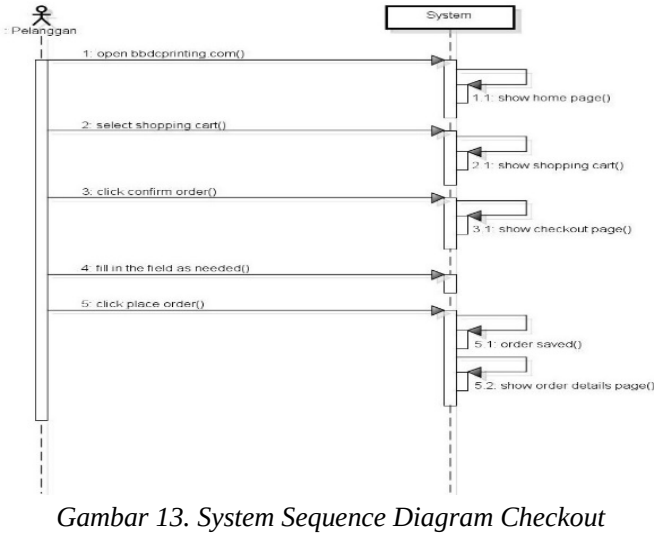

b. System Sequence Diagram Kelola Pesanan

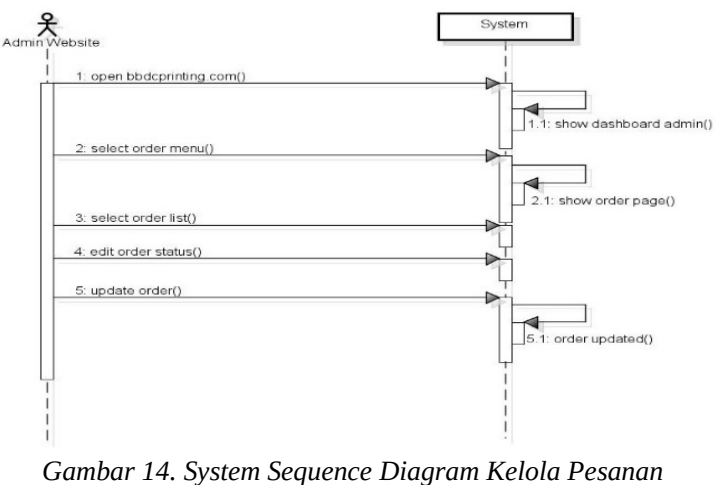

3.8. Hasil pengujian teknik SEO (Search Engine Optimization)

Berikut hasil - hasil test optimasi menggunakan Teknik SEO (Search Engine Optimization) a. Hasil pengujian SEO dengan nama domain website E-Commerce penjualan barang pada BBDC Screeen Printing

Hasil pengujian SEO dengan nama domain website E-Commerce dapat dilihat pada gambar 15 berikut ini :

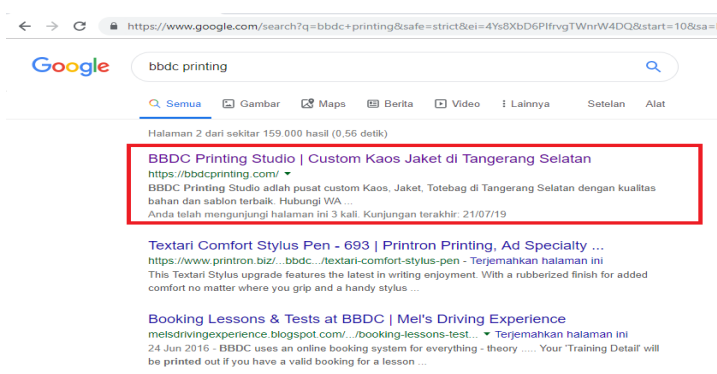

Gambar 15. Hasil Pengujian SEO Domain Website

b. Hasil pengujian SEO dengan nama Produk

Hasil pengujian SEO dengan nama produk pada website E-Commerce dapat dilihat pada gambar 16 berikut ini :

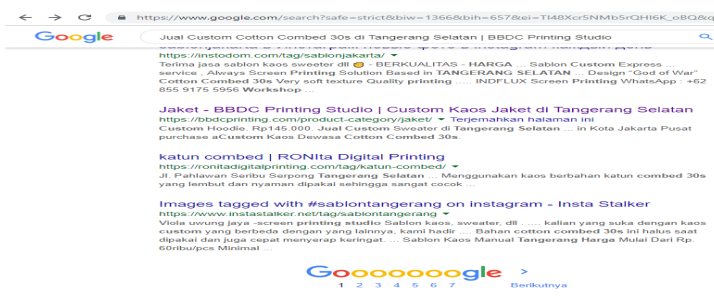

Gambar 16. Hasil Pengujian SEO pada Nama Produk

\section{KESIMPULAN}

Berdasarkan penelitian yang telah dilakukan pada BBDC Screen Printing, maka penulis dapat kesimpulan sebagai berikut:

a. Dengan pembangunan website E-Commerce yang berisi promosi dan katalog barang yang dijual pada BBDC Screen Printing, maka dapat membantu proses promosi menjadi lebih luas dan tidak terbatas.

b. Dengan adanya website E-Commerce penjualan barang dapat membantu pihak bbdcprinting.com memperluas jangkauan dalam hal pemasaran produk sehingga pelanggan tidak perlu datang ke toko untuk berbelanja.

c. Dengan adanya fitur fitur laporan pemesanan, penjualan barang dan laporan pendapatan, maka membantu pihak manajemen dalam mengetahui informasi terkait penjualan barang.

d. Dengan adanya penanganan transaksi dan konfirmasi secara otomatis yang dilakukan pada sistem e-commerce ini, maka menjadikaan layanan penjualan barang menjadi lebih efisien, efektif dan lebih mudah. 


\section{DAFTAR PUSTAKA}

[1] Sutabri, Tata. "Analisis Sistem Informasi". Yogyakarta: Andi. 2012.

[2] Turban, E., K, D., Lee, J., Liang, T. P., \& Turban, D. "Electronic Commerce.7th Edition. United States: Pearson”. 2012.

[3] Hastanti, R. P., Purnama, B. E., \& Wardati, I. U. Sistem Penjualan Berbasis Web (E-Commerce) Pada Tata Distro Kabupaten Pacitan. Bianglala Informatika, 2015. III(2), 1-9.

[4] Nugraha, A., \& Octasia, A. Sistem Informasi Penjualan Kaos Berbasis Web Pada Distro Sickness Berbasis E-Commerce. SNIPTEK, 2016. 299-302.

[5] Susandi, D., \& Sukisno. Sistem Penjualan Berbasis E-Commerce Menggunakan Metode Objek Oriented Pada Distro Dlapak Street Wear. Jurnal Sistem Informasi, 2017. IV, 5-8.

[6] Hamdani, Agus Umar dan Mubarak, Rakha Luri. "Model E-Commerce Dengan Metode Web Engineering Method Untuk Menunjang Pemasaran Produk Pada XYZ Pet Shop", Prosiding Seminar Nasional Multi Disiplin Ilmu Unisbank 2019, 2019. ISBN : 978-979. 